\title{
PENGARUH SELF CONFIDENCE SISWA SMP TERHADAP KEMAMPUAN BERPIKIR KREATIF MATEMATIS SISWA
}

\author{
Indiraningrum Pratiwi ${ }^{1}$, Dwi Yulianti ${ }^{2}$, Pamila Malinda ${ }^{3}$, Pipit Pitriyani ${ }^{4}$, Mira Siti \\ Hajar $^{5}$, Wahyu Hidayat ${ }^{6}$ \\ 1,2,3,4Program Studi Pendidikan Matematika IKIP Siliwangi, Jl. Terusan Jenderal Sudirman \\ 11pratiwiindiraningrum@gmail.com, 2dwi.ylt@gmail.com, ${ }^{3}$ pamilamalinda31@gmail.com, \\ 4pitriyani60@gmail.com, ${ }^{5}$ mirasitihajar@gmail.com, ${ }^{6}$ wahyu@ikipsiliwangi.ac.id
}

\begin{abstract}
This research aims to know the influence of student's self-confidence against the ability of mathematical creative thinking of students. Methods used correlational with quantitative approach. Samples taken is as much as 30 students are subjected to an SMP in the city of Cimahi. The instruments used in this research consists of a test and non-test. The results of this research are the self-confidence of students have a positive effect on the ability of mathematical creative thinking of the students of $10.9 \%$ and $89.1 \%$ influenced by factors other than the self-confidence.
\end{abstract}

Keywords: Mathematical Creative Thinking Ability, Self-Confidence.

\begin{abstract}
Abstrak
Penelitian ini bertujuan untuk mengetahui pengaruh self confidence siswa terhadap kemampuan berpikir kreatif matematis siswa. Metode yang digunakan yaitu korelasional dengan pendekatan kuantitatif . Sampel yang diambil adalah sebanyak 30 siswa disalah satu SMP di Kota Cimahi. Instrumen yang digunakan dalam penelitian ini terdiri dari tes dan non tes. Hasil dari penelitian ini adalah self confidence siswa memiliki pengaruh positif terhadap kemampuan berpikir kreatif matematis siswa sebesar $10,9 \%$ dan $89,1 \%$ dipengaruhi oleh faktor lain diluar self confidence.
\end{abstract}

Kata Kunci: Kemampuan Berpikir Kreatif Matematis, Self-Confidence.

How to cite: Pratiwi, I., Yulianti, D., Malinda, P., Pitriani, P., Hajar, M. S., \& Hidayat, W. (2018). Pengaruh Self Confidence Siswa SMP terhadap Kemampuan Berpikir Kreatif Matematis Siswa. JPMI - Jurnal Pembelajaran Matematika Inovatif, 1 (4), 667-672.

\section{PENDAHULUAN}

Berpikir kreatif sebagai kemampuan untuk melihat kemungkinan penyelesaian terhadap suatu masalah yang beragam, bentuk pemikiran tersebut kurang mendapat perhatian dalam dunia pendidikan sampai saat ini (Munandar, 2009). Oleh karena itu kemampuan berpikir kreatif merupakan salah satu kemampuan berpikir yang sangat penting untuk dimiliki oleh peserta didik (Andiyana, Maya, \& Hidayat, 2018; Dilla, Hidayat, \& Rohaeti, 2018; Hidayat, 2011; 2012; 2017; Hidayat, \& Prabawanto, 2018; Sumarmo, Hidayat, Zukarnaen, Hamidah, \& Sariningsih, 2012). Berdasarkan hasil penelitian yang telah dilakukan oleh Ismara, Halini \& Suratman (2017) dengan hasil penelitiannya adalah pencapaian dari beberapa indikator kemampuan berpikir kreatif matematis masih sangat rendah. Oleh karena itu diperlukan penelitian lebih lanjut untuk mengetahui penyebab rendahnya kemampuan berpikir kreatif matematis siswa.

Dalam berpikir kreatif diperlukan sikap yakin dan percaya terhadap kemampuan dirinya sendiri, salah satu sikap yang diperlukan yaitu self confidence. Menurut Lestari \& Yudhanegara 
(2015) Self confidence yaitu suatu sikap percaya dan yakin pada diri sendiri dan memandang diri sendiri sebagai pribadi yang utuh dengan mengacu pada konsep diri. Sehingga self confidence dapat menunjang keberhasilan siswa dalam menyelesaikan permasalahan matematika khususnya dalam kemampuan berpikir kreatif matematis (Sumarmo, Mulyani, \& Hidayat, 2018; Tresnawati, Hidayat, \& Rohaeti, 2017).

Berdasarkan hal tersebut, sehingga perlu dilakukan penelitian untuk melihat seberapa besar pengaruh self confidence terhadap kemampuan berpikir kreatif matematis.

\section{METODE}

Metode yang digunakan dalam penelitian ini adalah metode korelasional dengan pendekatan kuantitatif. Metode ini bertujuan untuk mencari pengaruh atau hubungan antara dua variabel atau lebih. Populasi dari penelitian ini adalah siswa SMP di kota Cimahi. Sedangkan sampelnya adalah sebanyak 30 siswa di salah satu SMP di kota Cimahi. Instrumen dalam penelitian ini terdiri dari tes kemampuan berpikir kreatif matematis dan angket self confidence. Instrumen tes kemampuan berpikir kreatif matematis terdiri dari 5 butir soal dan angket self confidence sebanyak 41 skala pernyataan.

\section{HASIL DAN PEMBAHASAN}

\section{Hasil}

Sebelum dilakukan uji statistika regresi, dilakukan terlebih dahulu uji normalitas data dan uji linearitas. Hasil uji normalitas data disajikan pada tabel 1 berikut ini.

Tabel 1. Uji Normalitas Data

\begin{tabular}{lcrrr}
\hline & \multicolumn{3}{c}{ Kolmogorov-Smirnov(a) } \\
\hline \multirow{3}{*}{ Tes } & Statistic & $\mathrm{df}$ & \multicolumn{1}{c}{ Sig. } \\
angket &, 131 & & 30 &, $200(*)$ \\
&, 155 & 30 &, 064 \\
\hline
\end{tabular}

Berdasarkan hasil uji normalitas di atas terlihat bahwa nilai sig $>\alpha=0.05$. Sehingga data tersebut berdistribusi normal.

Selanjutnya dilakukan uji linearitas kemampuan berpikir kreatif matematis atas self confidence siswa. Hasil uji linearitas disajikan pada tabel 2 berikut.

Tabel 2. Uji Linearitas Data

\begin{tabular}{|c|c|c|c|c|c|c|c|}
\hline & & & $\begin{array}{c}\text { Sum of } \\
\text { Squares }\end{array}$ & df & Mean Square & $\mathbf{F}$ & Sig. \\
\hline tes & Between & (Combined) & & & & & \\
\hline $\begin{array}{l}* \\
\text { ang }\end{array}$ & Groups & & 13436,667 & 19 & 707,193 & 1,334 & ,328 \\
\hline & & $\begin{array}{l}\text { Linearity } \\
\text { Deviation from Linearity }\end{array}$ & $\begin{array}{r}2044,998 \\
11391,669\end{array}$ & $\begin{array}{r}1 \\
18\end{array}$ & $\begin{array}{r}2044,998 \\
632,870\end{array}$ & $\begin{array}{l}3,858 \\
1,194\end{array}$ & $\begin{array}{l}, 078 \\
, 399\end{array}$ \\
\hline & Within Groups & & 5300,000 & 10 & 530,000 & & \\
\hline & Total & & 18736,667 & 29 & & & \\
\hline
\end{tabular}

Berdasarkan hasil uji linearitas di atas, terlihat bahwa terdapat hubungan yang linear antara self confidence dan kemampuan berpikir kreatif matematis. Hal ini dikarenakan nilai Sig Deviation from Linearity $>\alpha=0,05$. 
Selanjutnya dilakukan uji statistika regresi untuk melihat apakah terdapat pengaruh self confidence siswa terhadap kemampuan berpikir kreatif matematis. Hasil pengujiannya disajikan pada tabel 3, tabel 4 dan Tabel 5. berikut ini.

Tabel 3. Uji Regresi Data

\begin{tabular}{|c|c|c|c|c|c|c|}
\hline Model & & $\begin{array}{c}\text { Sum of } \\
\text { Squares }\end{array}$ & Df & Mean Square & $\mathbf{F}$ & Sig. \\
\hline \multirow[t]{3}{*}{1} & Regression & 2044,998 & $\overline{1}$ & 2044,998 & 3,430 & ,075(a) \\
\hline & Residual & 16691,669 & 28 & 596,131 & & \\
\hline & Total & 18736,667 & 29 & & & \\
\hline
\end{tabular}

Berdasarkan pengujian regresi pada Tabel 3, didapat nilai sig sebesar 0,075 yang menunjukkan bahwa self confidence siswa secara signifikasi memberikan pengaruh yang positif terhadap kemampuan berpikir kreatif matematis siswa dengan taraf signifikasi 5\%.

Tabel 4. Model Summary

\begin{tabular}{llrrr}
\hline Model & R & R Square & $\begin{array}{c}\text { Adjusted R } \\
\text { Square }\end{array}$ & $\begin{array}{l}\text { Std. Error of } \\
\text { the Estimate }\end{array}$ \\
\hline 1 &, 330 (a) &, 109 &, 077 & 24,41579 \\
\hline
\end{tabular}

Berdasarkan hasil pada Tabel 4, besar koefisien korelasi adalah 0,330 yang menunjukkan bahwa hubungan antara self confidence siswa dengan kemampuan berpikir kreatif matematis siswa tergolong lemah dan nilai koefisien determinasi sebesar 0,109. Hal ini dapat diartikan bahwa kemampuan berpikir kreatif matematis siswa dipengaruhi oleh self confidence siswa sebesar 10,9\% dan 89,1\% dipengaruhi oleh faktor lain di luar self confidence siswa.

Tabel 5. Coefficients

\begin{tabular}{|c|c|c|c|c|c|c|}
\hline \multirow[b]{2}{*}{ Model } & & \multicolumn{2}{|c|}{$\begin{array}{c}\text { Unstandardized } \\
\text { Coefficients } \\
\end{array}$} & \multirow{2}{*}{$\begin{array}{c}\begin{array}{c}\text { Standardized } \\
\text { Coefficients }\end{array} \\
\text { Beta } \\
\end{array}$} & \multirow{2}{*}{ t } & \multirow{2}{*}{$\begin{array}{c}\text { Sig. } \\
\text { Std. Error }\end{array}$} \\
\hline & & B & Std. Error & & & \\
\hline 1 & (Constant) & $-17,528$ & 39,770 & &,- 441 & ,663 \\
\hline & angket & ,603 & ,326 & ,330 & 1,852 & ,075 \\
\hline
\end{tabular}

Berdasarkan hasil pada Tabel 5, hasil pengujian tentang pengaruh self confidence siswa terhadap kemampuan berpikir kreatif matematis siswa yaitu :

$$
Y=-17,528+0,603 x
$$

Hal ini dapat diinterpretasikan bahwa apabila self confidence siswa bernilai 0, maka kemampuan berpikir kreatif matematis siswa bernilai -17,528. Selain itu terlihat juga bahwa koefisien dari self confidence siswa bernilai positif yaitu sebesar 0,603 artinya terdapat pengaruh yang positif antara self confidence siswa terhadap kemampuan berpikir kreatif matematis siswa. Sehingga dapat disimpulkan bahwa semakin tinggi self confidence yang dimiliki siswa, maka akan semakin tinggi pula kemampuan berpikir kreatif matematis siswa tersebut. 


\section{Pembahasan}

Berikut soal dan jawaban siswa pada soal tes kemampuan berpikir kreatif matematis :

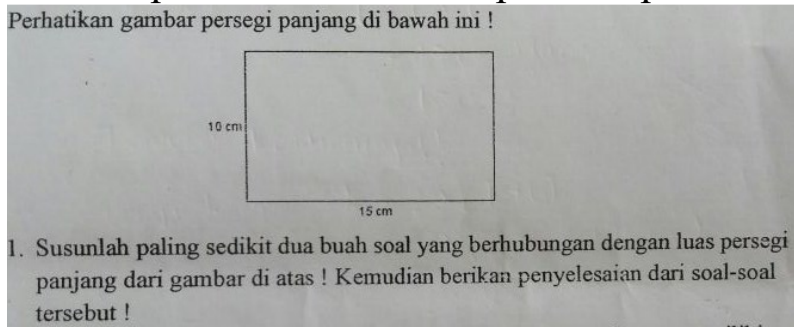

Gambar 1. Soal Tes Kemampuan Berpikir Kreatif Matematis

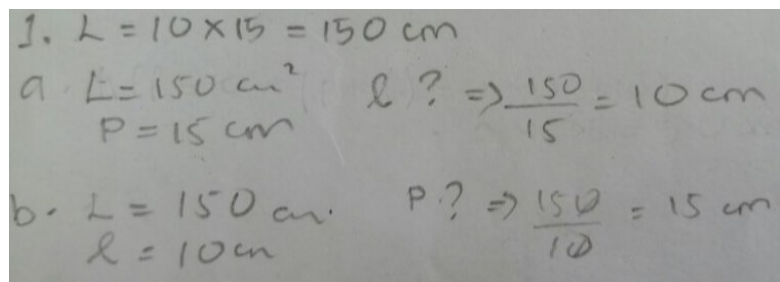

Gambar 2. Jawaban Siswa dengan Self Confidence yang Kurang

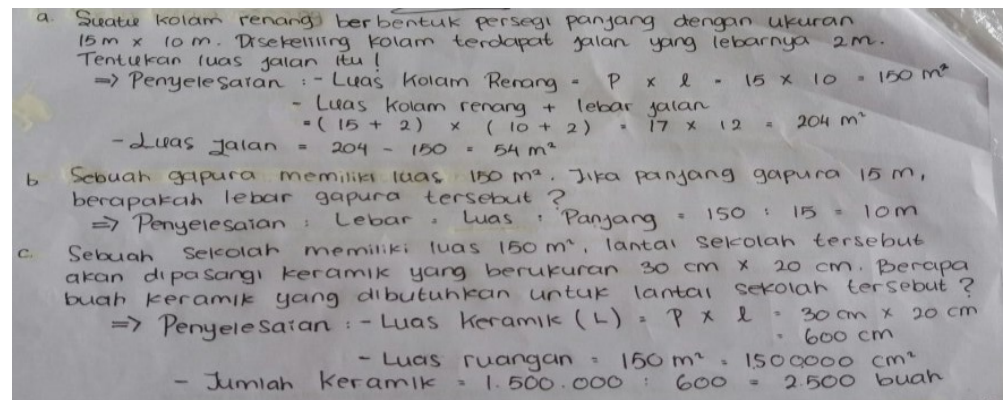

Gambar 3. Jawaban Siswa dengan Self Confidence yang Baik

Berdasarkan Gambar 1 siswa diminta untuk memberikan jawaban berupa pertanyaan dan penyelesaiannya sesuai dengan gambar yang diberikan, namun pada Gambar 2 siswa hanya menyantumkan penyelesaiannya saja. Hal ini dipengaruhi oleh kurangnya self confidence siswa sehingga jawaban yang diberikan siswa sangat sederhana. Sedangkan pada Gambar 3 siswa memberikan jawaban berupa pertanyaan yang dikaitkan dengan kehidupan sehari-hari serta jawaban yang diberikan lebih beragam dan berbeda dari yang lain. Terlihat bahwa dengan self confidence yang baik akan berpengaruh terhadap jawaban yang diberikan. Hal tersebut sejalan dengan pendapat (Hendriana, 2012) bahwa motivasi untuk mencapai keberhasilan dipengaruhi oleh self confidence karena dengan tingginya self confidence maka siswa akan lebih percaya terhadap kemampuan dirinya sendiri dan akan memperkuat semangat untuk menyelesaikan pekerjaannya.

\section{KESIMPULAN}

Berdasarkan hasil dan pembahasan diperoleh bahwa self confidence siswa memiliki pengaruh positif terhadap kemampuan berpikir kreatif matematis siswa sebesar 10,9\% dan 89,1\% dipengaruhi oleh faktor lain diluar self confidence. Terlihat bahwa terdapat perbedaan dalam jawaban yang diberikan antara siswa yang memiliki self confidence yang kurang dengan siswa yang memiliki self confidence yang baik. 


\section{DAFTAR PUSTAKA}

Andiyana, M. A., Maya, R., \& Hidayat, W. (2018). ANALISIS KEMAMPUAN BERPIKIR KREATIF MATEMATIS SISWA SMP PADA MATERI BANGUN RUANG. JPMI (Jurnal Pembelajaran Matematika Inovatif), 1(3).

Aripin, U., \& Purwasih, R. (2017). Penerapan Pembelajaran Berbasis Alternative Solutions Worksheet Untuk Meningkatkan Kemampuan Berpikir Kreatif. AKSIOMA: Jurnal Program Studi Pendidikan Matematika, 6(2), 225-233.

Dilla, S. C., Hidayat, W., \& Rohaeti, E. E. (2018). Faktor Gender dan Resiliensi dalam Pencapaian Kemampuan Berpikir Kreatif Matematis Siswa SMA. Journal of Medives, 2(1), 129-136.

Hendriana, H. (2012). Pembelajaran Matematika Humanis dengan Metaphorical Thinking untuk Meningkatkan Kepercayaan Diri Siswa. Infinity Journal, 1(1), 90-103.

Hidayat, W. (2011). Meningkatkan Kemampuan Berpikir Kritis dan Kreatif Matematik Siswa Melalui Pembelajaran Kooperatif Think-Talk-Write (TTW) (Doctoral dissertation, Universitas Pendidikan Indonesia).

Hidayat, W. (2012). Meningkatkan Kemampuan Berpikir Kritis dan Kreatif Matematik Siswa SMA Melalui Pembelajaran Kooperatif Think-Talk-Write (TTW). In Seminar Nasional Penelitian, Pendidikan dan Penerapan MIPA.

Hidayat, W. (2017). Adversity Quotient dan Penalaran Kreatif Matematis Siswa SMA dalam Pembelajaran Argument Driven Inquiry pada Materi Turunan Fungsi. KALAMATIKA Jurnal Pendidikan Matematika, 2(1), 15-28.

Hidayat, W., \& Prabawanto, S. (2018, January). Improving students' creative mathematical reasoning ability students through adversity quotient and argument driven inquiry learning. In Journal of Physics: Conference Series (Vol. 948, No. 1, p. 012005). IOP Publishing.

Ismara, L., Halini \& Suratman, D. (2017). Kemampuan Berpikir Kreatif Matematis Siswa dalam Menyelesaikan Soal Open Ended di SMP. Jurnal Pendidikan Dan Pembelajaran Untan Pontianak, 6(9).

Lestari, E. K \& Yudhanegara, M. R. (2015). Penelitian Pendidikan Matematika. Bandung: Refika Aditama.

Munandar, U. (2009). Pengembangan Kreatifitas Anak Berbakat. Jakarta: Rineka Cipta.

Sumarmo, U., Hidayat, W., Zukarnaen, R., Hamidah, M., \& Sariningsih, R. (2012). Kemampuan dan Disposisi Berpikir Logis, Kritis, dan Kreatif Matematik (Eksperimen terhadap Siswa SMA Menggunakan Pembelajaran Berbasis Masalah dan Strategi ThinkTalk-Write). Jurnal Pengajaran MIPA, 17(1), 17-33. 
Sumarmo, U., Mulyani, E., \& Hidayat, W. (2018). Mathematical Communication Ability and Self Confidence Experiment with Eleventh Grade Students Using Scientific Approach. JIML-Journal of Innovative Mathematics Learning, 1(1), 19-30.

Tresnawati, T., Hidayat, W., \& Rohaeti, E. E. (2017). Kemampuan Berpikir Kritis Matematis dan Kepercayaan Diri Siswa SMA. Symmetry: Pasundan Journal of Research in Mathematics Learning and Education, 2(2), 39-45. 